\title{
Epithelioid Cell Nevus
}

National Cancer Institute

\section{Source}

National Cancer Institute. Epithelioid Cell Nevus. NCI Thesaurus. Code C66757.

A nevus characterized by the presence of large epithelioid melanocytes. 